technologist in the broader sense, the student of material culture. It is upon this class of evidenee that the archæologist, the ethnologist and the student of early culture generally so largely rely. In the modern museum building, however, the trend of development is to make provision for the worker in technological research by withdrawing the bulk of the material in which he is interested from public exhibition, while the public galleries are given over to the more striking objects or to those of most educative value to the public. Doubtless when more space is given to our great public collections, the same method of procedure will be followed, and the public galleries will then be devoted to regional methods of display, in so far as these may have approved themselves as the most effective for purposes of instruction.

\section{Publication of Old Scientific Works}

A smaxl committee, presided over by Prof. B. Nemeč, met at Prague on December 3 and 4 to study, on behalf of the International Organisation for Intellectual Co-operation, the possibility of publishing old scientific works. This question had been raised by Prof. Nemeč, on behalf of the Czechoslovak Research Council, and had been adopted as part of the plan of scientific work of the International Organization for Intellectual Co-operation, by the executive committee of the International Council of Scientific Unions, acting as a committee of scientific advisers. The committee at Prague unanimously agreed that it would be desirable to publish a number of manuscripts or works on the exact and natural sciences, printed copies of which are extremely rare or almost inaccessible. A series of this kind would show the common origins of modern scientific culture and would be of great value to all savants interested in the historical development of the sciences. Considering the strictly international character of the undertaking, the committee felt that it should be entrusted to the International Organisation for Intellectual Co-operation. Further, the series should not be confined to one branch of science alone and it should embrace all the periods in the development of science since the Middle Ages.

THE publications envisaged may be divided into two series: Facsimiles relating to very rare manuscripts or works containing engravings or illustrations indispensable for the value of such works; and reprints of fundamental classical works in the development of the sciences, copies of which are extremely rare or no longer obtainable, including manuscripts that have never been printed. The committee suggested the publication in facsimile of the following manuscripts in the order given : (1) "De Revolutionibus orbium coelestium", by Nicolaus Copernicus ; (2) "De proprietatibus rerum", by Bartholomeus Anglicus (facsimile reproduction of the illustrations which appeared in all the editions, summary of each chapter of the original work, and a biography of the author); (3) "Micrographia", by Robert Hooke. In addition, the committee suggested the reprinting of the following very rare works and hitherto unpublished manuscripts in the order given : (1) "New System of Chemical Philosophy", by John Dalton; (2) a selection of letters from the scientific correspondence of Johannes Hevelius, astronomer and selenographer, the greater part of which is at the Bibliothèque Nationale, Paris ; (3) "Opuscula Botanitii argumenti", by Rudolf Camerarius ; (4) "De solido intra solidum naturaliter contento", hy Nicolaus Steno ; (5) "Origin of Species", by Darwin (a reprint of the first edition, 1859); (6) "Expériences pour servir à l'histoire de la génération des animaux et des plantes", by Lazaro Spallanzani; and (7) "Disquititio de sexu plantarum", by Linnæus.

\section{Excavations in North Syria}

At the Friday evening discourse at the Royal Institution on January 21, Sir Leonard Woolley described "Excavations in North Syria". The object of the North Syrian Expedition has been to trace such relations as may have existed between Asia and the early Greek world, especially during and before the rise of the Cretan civilization. Two sites were chosen on the trade-route afforded by the Orontes valley. One was at al Mina, at the river mouth, one at Atchana in the Amk plain where the road debouches from the mountain range and runs across open country past Aleppo to Carchemish and the Mesopotamian centres. At al Mina, underlying the ruins of the crusading port of St. Simeon, there were found nine further strata giving a continuous record of commercial activity from 300 B.c. back to the beginning of the eighth century. During the fifth and fourth centuries Athens, in spite of the longdrawn crisis of the Persian wars, enjoyed a trade monopoly with Persia. In the sixth century B.c. the bulk of the trade was in the hands of the Rhodian manufacturers, but Corinth, Naukratis and Lesbos secured a certain amount of it and Cyprus was still selling goods in Asia although in greatly reduced measure. In the seventh century, judging by al Mina, Cyprus entirely controlled the market; of all the imported pottery found there scarcely a sherd is not Cypriote. This domination had come about quite suddenly. It was a natural result of the wealth of the Asiatic clientele that the al Mina merchants imported always the best wares that were to be obtained; from each manufacturing centre the finest quality was selected and the centre changed according as its level of production rose or fell.

THE earlier strata of al Mina have been eroded by the river; for the period preceding the eighth century we have to look at the second site. The topmost stratum at Atchana is dated by imported Mycenæan pottery to the twelfth century B.c. In the second stratum below this, dated to the 15th-14th centuries, there are the earlier Mycenæan wares side by side with a remarkable painted pottery which is undoubtedly local, in some aspects identical with the 'Hurrian' wares found on other sites, in others altogether novel in Asia but strikingly reminiscent of Knossos. The city in which this pottery occurs, and 